\title{
What should Daddy do in the Great War?: The Second Division Question and Conditional Commitment within New Zealand's War Effort, 1917-1918
}

\author{
STEVEN LOVERIDGE
}

\begin{abstract}
At the beginning of 1917, the prospect of extending conscription to Second Division men (men who were husbands and/or fathers) loomed. This was a development many had sought to delay out of concern for the social issues and potential tensions it would raise. This article examines reactions to the Second Division question as a case study of the conditional commitment within New Zealand's war effort. It outlines the events and dynamics of the case, and considers how the conditions of service were negotiated, challenged and enforced across 1917-1918.
\end{abstract}

In early 1917, New Zealand faced the looming prospect of conscription being extended to husbands and fathers, a scenario that many had acted to delay and had hoped to avoid. For a society esteeming family life and male breadwinners, the conscription of these Second Division men promised increased social and economic upheaval. ${ }^{1}$ In a letter to the Defence Department, the Wellington Chamber of Commerce warned that the development would impact industry: "the business of the Dominion (both farming and commercial) is largely in the hands of men eligible for service under the Second Division classification."2

Consequent angst over how the welfare of Second Division dependants would be secured risked damaging an underlying philosophical assurance that enlistment represented the protection of both a man's loved ones and his country. For a government seeking to preserve social harmony, the move raised anxieties over its potential to harm the social consensus around conscription. This was a legitimate concern, and over 1917-1918 the Second Division question became a politicised and, in places, radicalised issue. At the centre of this development was the Second Division League, which emerged to represent the interests of this new contingent of potential conscripts. The league's record forms a curious mix of staunch support for the war, strident critiques of the war effort's management, and a direct connection to one of the most dramatic episodes of dissent in New Zealand through 1914-1918.

This article examines the history of the Second Division question and considers it as a case study of the boundaries of New Zealand society's commitment to the war. ${ }^{3}$ That parts of society were outside these boundaries has been recognised by scholarly and public interest in pacifist and antiwar movements. ${ }^{4}$ However, if these movements show that commitment was neither universal nor uncontested, the Second Division question provides a case where commitment was present but conditional. Indeed, the Second Division League's rationale was that their members' compliance was contingent upon the circumstances of their service. Their efforts to leverage political and public capital can be located within a broader nexus of forces, all of which illustrate the significance of conditions in shaping commitment in wartime New Zealand. 
The events and dynamics of the Second Division question can be contextualised against the legitimacy challenges various belligerents experienced in the latter part of the war. As historian David Stevenson notes, "beneath the fraying political truce a contest developed between the underpinnings of patriotic consensus and the pressures that would fracture military discipline and social cohesion in one belligerent after another in 1917-1918." Certainly, tensions over the Second Division correlated with rising discord. Paul Baker's study of conscription, the sole detailed study of the Second Division question, observes the league's actions as part of "the wartime polarization of New Zealand society." towards other groups, and it is noted that many, arguably the worst, of New Zealand's social upheavals reflected "not the absolute demands of the war but the equitable sharing of sacrifices." 7 Targets included enemy aliens who were exempt from service, profiteers denunciated for making fortunes whilst others made sacrifices, and various groups - militant labour, Catholics and Waikato-Maniapoto Maori-accused of shirking. ${ }^{8}$

Against this polarisation, and with social commitment no longer assured, belligerents sought to "remobilise" their efforts by buttressing social consensus with concessions and by suppressing dissent via assorted measures. ${ }^{9}$ For a variety of reasons, which warrant further study, the fraying and reassertion of New Zealand's commitment was milder than that experienced by many other belligerents. ${ }^{10}$ However, mildness should not be overstated and the following record of social discord and state coercion attests to this.

\section{Historical Context, May 1915-January 1917}

In May 1915, details of casualties from the start of the Gallipoli campaign began to trickle back to New Zealand, spurring fresh commentary on the manpower needs of the war and the potential sacrifices society might be required to make. Within this commentary, a general consensus emphasising the desirability of single men enlisting over family men can be observed. Besides the aforementioned wish to preserve family life, many noted the rationale of avoiding, as much as possible, the associated expenses represented by separation allowances and widows pensions. ${ }^{11}$ As one commentator noted:

There is a great difference in a single man enlisting and a married man doing the same thing ... The fighting qualities of the two men may be equal, but one is a more important economic factor to the Dominion than the other ... To send married men to the front before making efforts to enlist every single man available would be a costly business for the Dominion. Already we know of cases where married men have been killed, and now the State must keep a widow and three or four children. ${ }^{12}$

However, the possibility of family men serving was not presented as unthinkable. May 1915 also saw the Minister of Defence, James Allen, encouraging married men, if they were able, to enlist: "it must be for himself to decide if he possibly can go. I think the urgency is so great now that even a married man must make sacrifices for the defence of the Empire, which means he should remember the defence of his own home, his wife and children." 13 Despite such prompts, however, unmarried men would continue to constitute the bulk of New Zealand recruits, and by mid-1916 only some 7.6 percent of enlisted men were married. ${ }^{14}$

The system of conscription which New Zealand introduced at that time institutionalised the dynamic and continued to delay the question of whether husbands and fathers should be at home or at the front. While all men aged between 20 and 45 were registered as eligible for

Journal of New Zealand Studies NS27 (2018), 16-34

https://doi.org/10.26686/jnzs.v0iNS27.5174 
service, this reserve was split into two divisions dependant on familial statuses. First Division was constituted of men who were unmarried prior to 1 May 1915, along with widowers and divorcees with no children under 16. Second Division consisted of all other reservists. ${ }^{15}$ The system continued to accept volunteers, regardless of Division status, with balloting used to make up shortfalls in the enlistment quotas set for each military district. However, the system was designed so that no Second Division reservist would be balloted until a district's First Division men had been enlisted or exempted, whether that was on grounds of fitness, public interest, undue hardship or conscience (i.e. religious). ${ }^{16}$ Subsequent regulations, gazetted in July 1917, further subdivided the Second Division into Class A (married men without children), Class B (married men with one child), Class C (married men with two children), Class D (married men with three children), Class E (married men with four children) and Class F (married men with more than four children) with a district's Second Division Classes to be balloted in sequence. ${ }^{17}$

This delaying tactic was shaken in January 1917 when Allen announced an estimate that the First Division would soon be exhausted and that the first balloting of Second Division men would occur in July that year. ${ }^{18}$ In March, an adjusted estimate from the government statistician pushed this date back to November or December. ${ }^{19}$ Public recognition of the matter manifested in various ways. Lighter examples include the appearance of recurrent japes of family men staring down the coming trials of military life (figures 1 and 2) and commercial interests seeking to leverage business opportunities from new cohorts of men facing enlistment:

With the calling up of the Second Divison [sic] many business men and responsible heads of families will be concerned for the safe administration of their affairs while away on service. The safeguarding of securities and investments, collection of rents and interest, and watchful attention to financial requirements in general, are points about which persons will be seriously concerned at the present time. THE GUARDIAN TRUST AND EXECUTORS COMPANY OF NEW ZEALAND, LIMITED has been authorised by Parliament to undertake all such administrative work, and may with confidence be appointed. ${ }^{20}$

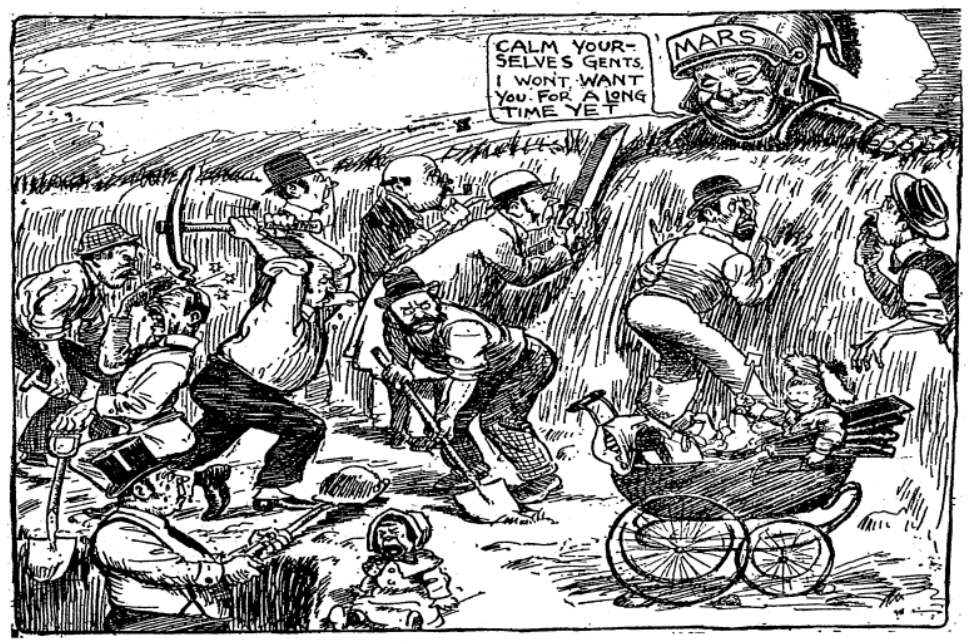

Digging Themselves In: Married Men getting. Panicky

Figure 1: Truth, 31 March 1917, 5.

Journal of New Zealand Studies NS27 (2018), 16-34

https://doi.org/10.26686/jnzs.v0iNS27.5174 


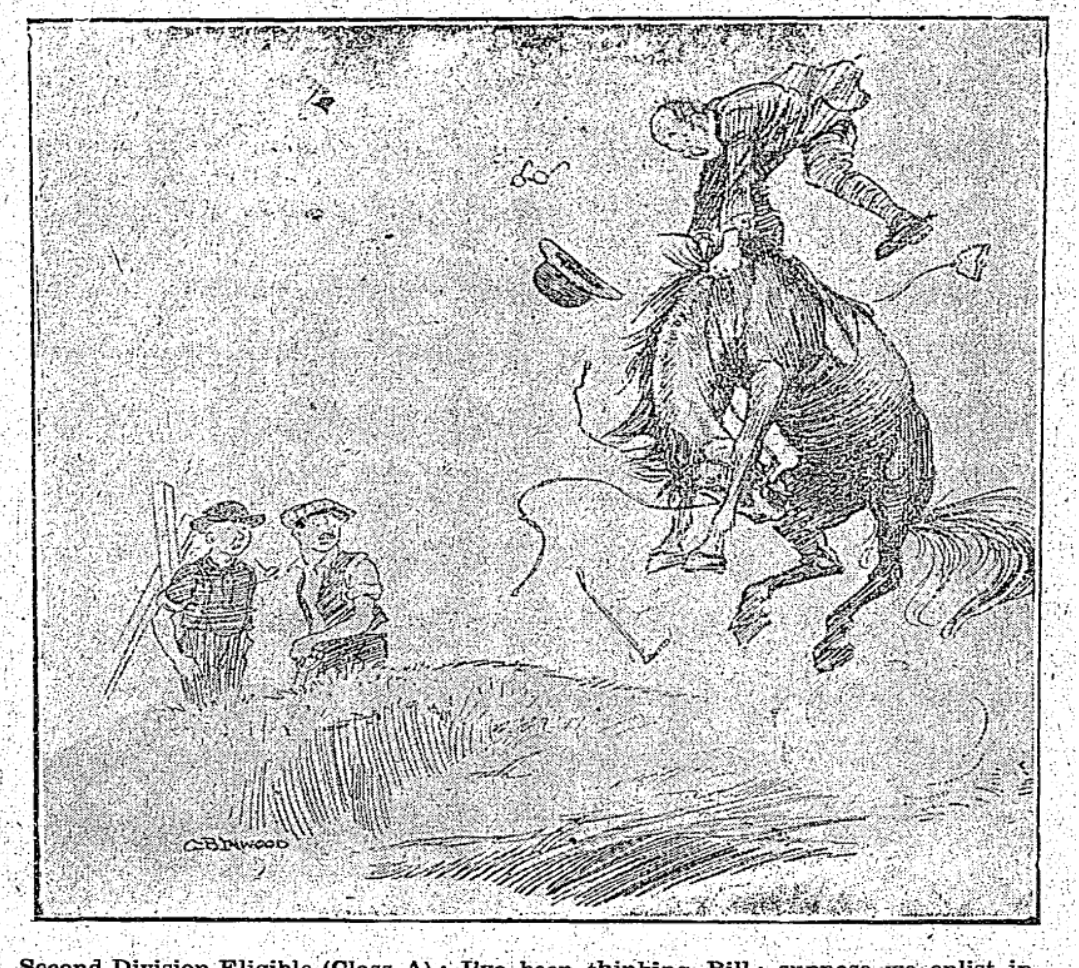

Second Division Eligible (Class A) : I've been thinking, Bill ; suppose we enlist in the infantry instead of the Mounteds?

Figure 2: New Zealand Free Lance, 12 October 1917, 22.

Thankfully, from the government's perspective, the major response to this news was a movement emphasising cooperative lobbying over militant dissent. ${ }^{21}$ The resulting Second Division League quickly secured a mass membership, and a study of patriotic organisations notes the league as "by far the most extensive of any patriotic organisation" beyond war relief associations. ${ }^{22}$ While detailed figures for the league's membership remain unknown, Auckland is noted as having an initial membership of 400 and the Otago region had over 6,500 members. ${ }^{23}$ Some 91 branch delegates, said to represent every town and city in the country, were present at the first national conference in July $1917 .{ }^{24}$

The league presented itself as a model of respectable civic responsibility, and conspicuously presented its goal of representing Second Division interests as wholly compatible with loyalty to the war effort. However, its proclamations also hinted at potential discord if its interests were not taken into account. For example, the first resolution at the July conference, which "carried unanimously with acclaim," was that the league "affirms the principle of carrying on New Zealand's part in the war to the end, provided the principle of equality of sacrifice be applied by legislation to the whole community." ${ }^{25}$ Likewise, the president of the league, Rupert Ashley Armstrong, inferred the limits of the Second Division's compliance in the published proceedings of the conference:

The first clause of our constitution is to the effect that we are organised to demonstrate our loyalty to his Majesty the King, and his government in New Zealand, by assisting in every way possible to carry this war to a victorious conclusion. I may say that in a few words addressed to the Minister of Defence at our conference the other day, I 
added "consistent to the duty to our dependants"; for the first law of nature is the protection a father gives to his children, and to the woman he married. ${ }^{26}$

Such an ethos matches that noted among the French troops of 1917: "Consent was real, but profoundly conditional." 27

Besides the conditions of service, the league's support of the war was also swayed by the antiwar influences joining it. For example, discussing the importance of "taking up active work in other organisations," the Southland District Labor [sic] Council specifically mentioned the Second Division League as "an opportune body to attempt capturing." ${ }^{28}$ Such influence was seemingly observed during the preliminary meeting of the Christchurch branch of the league. A motion that the league should endeavour to carry out the provisions of the Defence Act and the Military Service Act led to objections and an eventual rejection by 16 votes to 13 . Furthermore, motions affirming loyalty are noted as bringing similar "wrangling" and an eventual recess. ${ }^{29}$ According to one commentator, this result represented, not a failure of the league's purpose, but the presence, among the 35 attendees, of "a sort peculiar to Christchurch - anti-militarists, peace-at-any-price fools, conscientious objectors, soap-box Socialists, and heaven only knows what else." ${ }^{30}$ Such an observation reflected Christchurch's history as a hotspot of antimilitarist activism, a dynamic would prove influential in the record of the Christchurch branch. ${ }^{31}$

\section{The Fruits and Limits of Negotiation, July 1917-September 1917}

If such scenes hinted at potential league dissent, the league's emergence was generally perceived as revealing grounds for civil collaboration. The sheer numerical strength of the league facilitated a sense of mainstream legitimacy and its early days tapped a broad reserve of goodwill. Favourable media coverage presented league representatives as respectable family men and further brightened the league's image by demonising depictions of unmarried "shirkers" thumbing their noses while families were broken up. ${ }^{32}$ Even commentary denouncing Christchurch "cranks" impressed the worthiness of the league's aims and urged a sympathetic hearing: "There is a wide gulf between sense and sedition, and only fools may fall into it." ${ }^{33}$ Officials, too, impressed a sense of the league as representing right-minded citizens. In Parliament, many praised the league, with Charles Talbot, the Liberal MP for Temuka, for example, noting his sense that "the Second Division League is thoroughly loyal, and that all its members are willing to go to the front if need be. They have assured us that such is the case. They have not formed their league in order to shirk their duty." 34

The priorities of the league's campaigning also suggested grounds for fruitful negotiation. The issues raised at the league's first national conference were diverse and included various minute and practical considerations relating to departures from family and business life. Examples include provisions for overseas voting and the supply of official signs to signal that business owners had been called up. However, three broad areas emerged as central concerns. First, the league wanted all Second Division men to be medically examined as soon as possible to give them, on account of their greater business and social obligations, increased certainty over whether they were eligible for service. Second, they wanted efforts to ensure that First Division men were not unduly exempted before married men were balloted. Third, they called for state financial support for married conscripts to be increased. ${ }^{35}$ 
These areas represented ideal grounds for concessions. The business community welcomed measures to provide increased certainty over how the workforce would be impacted by Second Division conscription. ${ }^{36}$ Authorities were content to continue the general principle of delaying any balloting of Second Division men for as long as possible. This was certainly the position of Allen who, with Prime Minister William Massey and deputy leader Sir Joseph Ward attending conferences in London, was Acting Prime Minister for some 23 months of the war. In private correspondence, dated 7 May 1917, Allen noted that "it will be a great blessing if we can get the war over without calling on Second Division at all." 37 Officially he noted that "the Department would use its best efforts to secure all of [the First Division] before the Second Division was called on." 38 The league's call for increased financial support was also met with general acceptance, and the government committed itself to reviewing state support for soldiers' dependants, which had been kept low to discourage family men from enlisting. ${ }^{39}$

The result was a series of concessions and initiatives. A shortage of doctors and a wish to avoid the potential inaccuracies of outdated medical diagnoses deterred calls to examine all Second Division reservists before balloting commenced. ${ }^{40}$ However, the Defence Department calculated that it could provide balloted men with a three month window between medical examination and a departure into training camps to afford a degree of advanced warning. ${ }^{41}$ Furthermore, several initiatives were undertaken to delay Second Division balloting and "comb out" First Division men. These included a review of adjourned First Division exemptions; the reexamination of marginally unfit men; the opening of a health camp, intended to raise the fitness of marginally unfit men; a reduction in the reinforcement rate; and the reform of the enlistment system in which a district's shortfalls would be filled by balloting First Division men from across the country. ${ }^{42}$ Lastly, reevaluated rates for soldiers' dependants were announced on 26 September. Besides increasing the disability and widows' pensions, the new rates increased the separation allowance for a soldier's wife to 3 shillings a day (up from 1 shilling), the rate per child to 1 shilling (up from 9 pence) and increased the special financial assistance provision to 3 pounds per week (up from 1 pound). ${ }^{43}$

However, this period of negotiation also indicates that official and public goodwill towards the league was not a blank cheque and that the politics of sacrifice were fluid and capable of undermining the league's position as well as supporting it. For example, a proposal to inflate the First Division by lowering the enlistment age to nineteen was put before military and public opinion in late July 1917. While the military authorities were split on the initiative, it was ill received by a wide array of public associations and commentators. ${ }^{44}$ To take but one example, "A Soldier's Mother" noted:

We parents with our unmarried sons have kept this terrible war going nobly and uncomplainingly: we have done what we considered our duty, and now the Government proposes lowering the age limit. Is this fair? Will the married men sit quietly down and allow this? ... Now, as a wife and mother of fighting sons, I contend that every man who has a wife has a greater right to go to the front than any lad of nineteen. This is the feeling of most of the mothers. ${ }^{45}$

Protests included many Second Division League members who rejected the idea that they were, as the Maoriland Worker put it, "Abraham clamouring to be allowed to offer up Isaac." 46 As this suggests, the league was now on the wrong side of the politics of sacrifice. While the 
proposal was dropped, it was partially resurrected in the later decision to allow nineteen-yearolds to volunteer with parental consent. ${ }^{47}$

Likewise, league dissatisfaction with reevaluated rates for dependants appears to signal the onset of eroding goodwill. A day after the new rates were announced, a league deputation met with ministers and called for additional concessions. Their initiatives included: a call for further increases to the separation rates for wives and children, with a daily rate of 6 shillings for wives and 1 shilling and 6 pence for children proposed; an increase of the age limit for a daughter's pensions from 17 to when she was "of marriage age, say, 20 years"; and a recognition that Second Division men required a "nest egg" for a potentially unstable future. ${ }^{48}$ The ministers" responses mixed accentuations of the concessions already made, warnings that financial realities restricted possibilities and uncommitted acknowledgements that the adjusted rates were not perfect. However, many clearly saw the issue as resolved. Various commentators congratulated the government as "having solved a difficult issue both boldly and satisfactorily," noting "they must be unreasonable persons indeed who find room for serious complaint in the increased separation and special allowances." 49 One illustration of these concessions depicted a family man, pocketing a "big pensions" cheque, shaking hands with Allen and noting "Thanks; the war for me now my pension's right." To this Allen replies, "And may you never get it." 50

\section{Radicalisation, October 1917-April 1918}

This vision of mutual concord was premature, and the unresolved nature of the Second Division question was affirmed in October 1917, as the first Class A Second Division men were balloted and began their processing through medical exams and Military Service Boards, to test whether they were fit to serve or had acceptable reasons not to, before proceeding to training camps. The first reinforcement draft to include married men was due to mobilise on Monday 29 April $1918 .{ }^{51}$ Over the duration of the war, other Second Division gradations were similarly called up with the first Class B men being balloted from mid-April 1918 and Class C men from June. ${ }^{52}$ As this process began, rhetoric and activity around the issue became more energised and, in places, radical. Accusations that the government had failed in its obligations to Second Division men were voiced and calls for more far-reaching measures were raised. In October, a Second Division League conference saw claims that it was "not right that British men should be sent away to fight while aliens were left to enjoy all the privileges of citizenship of the Dominion ... The root of the evil lay at the door of Parliament." ${ }^{, 53}$ The populist editorial line of Truth encouraged the league to take a hard stance and to use their demands as leverage for a conscription of wealth. One cartoon depicted the Second Division urging the minister of finance, Joseph Ward (aka "Sir Joe") to bomb the capitalist bogey "Mr Fat" and accompanied this sentiment with a verse:

The married men do not object

To donning martial raiment.

To take a gun and chase the Hun,

Providing there's fair payment.

"It is not meet," they say with heat,

"While we the foe are hacking,

(Risking our lives),

Our little wives

And children should be lacking." 
"There's whips of money in the land,

That no one is denying.

The Fatman gloats on every hand,

So come, Sir Joe, a-flying.

That man of girth must leave the earth,

Let's bomb him to tarnation."

Will bold Sir Joe

Just answer "No."

Or take the invitation? $?^{54}$

By December, the Wellington branch was rumoured to be considering the formation of a political organisation to campaign in the Wellington North by-election, slated for February 1918. Ultimately, however, the branch elected to campaign for public and political support rather than institutional power. ${ }^{55}$ The progressively confrontational mood around the looming mobilisation of Second Division men was most evident in Christchurch where, by February 1918, it was noted that the Christchurch branch "has developed into a very lively and aggressive body, with a penchant for passing lengthy, comprehensive and strongly-worded resolutions." $" 56$ This radicalisation, both within and beyond the branch, can be charted in a series of meetings held as mobilisation approached, and demonstrates the growing influence of anticonscription and/or antigovernment positions.

On 4 February, a public and "lively meeting" for married reservists spotlighted the growing discontent towards and within the Christchurch branch as well as within Christchurch generally. Charges hurled at the Second Division League Branch President, M. J. Gresson, included accusations that he "was not a worker," that he was "in the Government [sic] pay" or that he had been "put into the League by the military people." Moreover, the meeting saw various motions raised calling for campaigning on more radical positions. These included, after a prolonged condemnation of the government's performance, a call for an early election (which carried unanimously); a declaration that the conscription of men should be abolished if it was not to be accompanied by a conscription of wealth (which lapsed); and the statement that Second Division men could best serve the Empire by staying at home and caring for their families (which carried). ${ }^{57}$ On 26 April, the Christchurch executive passed a resolution recommending that the National Executive declare that members of the league were "released from all obligations if the government did not grant the League's demands by May 31st next." 58

On the evening of 27 April, a meeting of Class A and B reservists was held and was advertised as having "no connection whatsoever with the Second Division League," which was accused of having "hopelessly failed to obtain a fair deal for the wives and children of conscripted men." ${ }^{59}$ The principal motion to "enter an emphatic protest against any more reinforcements being sent from New Zealand until a referendum of the people is taken, and ... that there be no industrial conscription of the wives and children of reservists" was among the far-reaching resolutions raised. It was noted as "carried unanimously midst scenes of tremendous enthusiasm." ${ }^{60}$ On the evening of Sunday 28 April, the eve before mobilisation, some 1,600 citizens packed the Opera House for a public meeting organised by the league and chaired by the mayor. Called to discuss the social impacts of the war, the meeting took a radical turn when an amendment was moved from the floor that "the first line of the Second Division shall not be broken and no Second Division man shall leave for camp until the demands of the league 
are acceded to." A marginally rephrased adaptation, which added the demand for a general election, was seconded and voted on with only two dissenting votes. ${ }^{61}$

This promised challenge saw mobilisation day begin with some dramatic manoeuvres. The morning paper carried an announcement of Gresson's resignation from the Christchurch branch of the league on account of Sunday's resolution. In correspondence and meetings with the local league representatives, politicians counselled restraint and/or distanced themselves from the organisation. Thus, George Witty, the Liberal MP for Riccarton, while noting some support for the league's motivations, urged moderation: "do not try to stop any man going to the barracks to-night." ${ }^{\prime 2}$ Harry Ell, the Liberal MP for Christchurch South, was more blunt, noting that he would not, "either directly or indirectly," be party "to a counsel of revolt as a means to gain what you are after." ${ }^{63}$ Leonard Isitt, the Liberal MP for Christchurch North, was perhaps still more damming, and stated "I cannot see my way to attend your meeting or in any way to identify myself with your executive as at present constituted." He added that:

If you have the right to refuse to defend your country, and to leave in the lurch your comrades who are desperately struggling against the Prussian hordes because injustices and inequalities exist that should be remedied, there is not a man who has died for you and yours, or who is today fighting in the Empire's defence, who had not an equal right to refuse service. ${ }^{64}$

Behind the scenes, these MPs were urging the government to make a statement on revising allowances. In a telegraph to Allen, they noted "very strong and anxious feeling here among Second Division men about the allowances to wives and children. Kindly state definitely, and make public, what Cabinet intends to do in regard to allowances to soldiers' dependants." 65 Allen's response, which came through late that night, noted: "The matter has been engaging attention since the session, and was finally disposed of in Cabinet today." 66 The new rate increased the separation allowance for a soldier's child to 1 shilling 6 pence (up from 1 shilling) per child per day, as well as offering additional provisions for widowed mothers and extending government support for life insurance policies. ${ }^{67}$ Commentators considered these further concessions as making the New Zealand soldier "the envy of all others who fight under less paternal Governments." ${ }^{68}$ Such commentary also noted "it is to be hoped, now that the Government has made these latest concessions, that the Second Division League will cease making further exorbitant demands." 69

However, the matter had evidently moved beyond negotiations between the state and the league, and these Monday announcements occurred as radical elements took to the streets. The result competes with Gisborne's and Wanganui's anti-German riots and the police raid on Maungapohatu as episodes of violence in First World War New Zealand. ${ }^{70}$ By media accounts, the public mood in Christchurch on Monday morning was one "agog with excitement."71 Towards $3.30 \mathrm{pm}$, a crowd, observed as consisting principally of women and estimated as five thousand strong, gathered outside Christchurch's King Edward Barracks, where the draft had been summoned to assemble and parade. Noted as "easily the largest [crowd] which has ever gathered to see a draft away," the mood within those assembled was described as "electric," "rather menacing," and as lacking "the usual light-hearted banter." "At first good humour appeared to prevail, hoots being only occasional and principally directed at members of the Defence staff"; Truth's correspondent stated that the crowd were concentrating their remarks upon the bagginess of Major Conway's trousers. However, when the rollcall was attempted,

Journal of New Zealand Studies NS27 (2018), 16-34

https://doi.org/10.26686/jnzs.v0iNS27.5174 
parts of the crowd actively disrupted procedures and the mood darkened: "the mob, thinking it had full control of the situation, vented its feelings in full-blooded hoots whilst the feminine portion spoke its opinion of the Defence staff officers present in very uncomplimentary terms."

Events escalated as the authorities attempted to proceed and keep to the transport schedule. When the departing North Canterbury draft marched, it was accompanied by women shouting "Don't go!" From here, pandemonium broke out on the adjacent Cashel Street, with the episode assuming "its ugliest aspect" as police struggled to clear the area. Press commentary provides snapshots of some of the resulting chaos. One "particularly exciting bout" was noted between a returned soldier and a burly opponent. One policeman, attempting to detain an "unduly obstreperous" youth in knickerbockers, was promptly attacked by a woman armed with an umbrella, who rescued the boy. The Mayor, spied on the balcony from which a farewell speech was customarily given, had clenched hands and threats raised at him. A mounted policeman appeared and for a moment seemed to consider riding into the crowd, but he evidently thought better of it and disappeared, "much to the relief of many of the spectators." A young man, in some accounts a half-drunken Australian, assaulted a policeman, and when an attempt was made to arrest him the crowd rushed to his rescue and the arresting officers were observed as having "a distinctly bad quarter of an hour." The officers eventually succeeded in hauling the man into the barracks' grounds, accompanied by some 300 members of the crowd. A general melee lasting for a quarter of an hour occurred until a Senior Sergeant ordered the release of the arrested man. By five o'clock, things had quietened down and the building was cleared. The demonstrators had succeeded in creating enough chaos to prevent the army taking a rollcall and preventing, or dissuading, about half the men from mobilising.

Against the upheaval, and body count, experienced by many other belligerent societies, the situation on Cashel Street on 29 April 1918 is less than a minor footnote. The immediate disruptions it offered to mobilisation were fleeting, and by 1 May only 18 men in the Christchurch draft were unaccounted for, and only 6 of these men were Second Division. ${ }^{72}$ Furthermore, as Paul Baker notes, with Second Division men never constituting a critical mass in any given reinforcement, Second Division dissent, by itself, had a limited potential to undermine mobilisation. ${ }^{73}$ However, the episode does vividly showcase the extent to which dissent against the conduct and/or cause of the war had become politicised and radicalised in New Zealand. That this had occurred over an issue in which leading parties impressed their willingness to cooperate and their acceptance of the legitimacy of the war is also telling.

\section{Remobilisation, May 1918-November 1918}

In retrospect, 29 April 1918 proved a high-water mark of destabilisation over the Second Division question. What followed constitutes an example of remobilisation, in which measures of concession and coercion were employed to isolate radical dissent and reengage social commitment to the war.

In Christchurch, this process began in a volatile milieu, as observed from various perspectives. A self-described antimilitarist speaking at a women's meeting declared that there was a "strong undercurrent of feeling which only required one to set a match to the flame."74 Isitt echoed the assessment, warning Allen that "we are on the edge of very serious trouble." 75 Loyalists at the Press concurred and appealed for tough measures, proclaiming that "the Bolsheviks must not be allowed to bring the rest of the city into disgrace. We call upon the Government to take

Journal of New Zealand Studies NS27 (2018), 16-34

https://doi.org/10.26686/jnzs.v0iNS27.5174 
vigorous steps to put down anything in the shape of sedition." targets were those who, at the 28 April meeting, had authored, proposed and seconded the motion not to comply with conscription unless the league's demands were met. Consequently, on 8 May, three men-John Flood, Ernest Langley and Hiram Hunter-were found guilty of sedition, with Flood and Langley sentenced to six months imprisonment and Hunter to three months. ${ }^{77}$ However, on 21 May, a Cabinet meeting elected, as part of an effort to mend industrial relations, to suspend these sentences in exchange for promises of good behaviour. ${ }^{78}$

Commenting on the league's position in regard to the events of 29 April, the New Zealand Free Lance noted that "it is quite clear that the 'Red Feds' ever on the watch for an opportunity of fomenting contempt for and defiance of constituted authority are hoping to utilise Second Division discontent for their own revolutionary ends." It called on the Second Division leadership to "weed out the skulking, shirking, disloyalist element without delay." 79 This process was already underway in an internal battle between radicals and loyalists within the Christchurch branch. On 2 May, 3 days after the disturbance, a motion was submitted to rescind the 26 April resolution, recommending that league members were "released from all obligations if the Government did not grant the League's demands by May 31st next." Furthermore, the members responsible for that motion were requested to immediately resign. ${ }^{80}$ This motion was lost, 48 to 34, and the Press deemed this "Bolshevik triumph" to be the result of packing the meeting with hastily enrolled waterside workers. ${ }^{81}$ However, the national executive of the Second Division League took action to isolate itself from the Christchurch situation. In an open letter to the Christchurch branch, President Armstrong denounced the "recent determinations" as a breach of the league's constitution: "I look to you to maintain hold of the original Christchurch League, in accordance with the constitution. Let extremists leave and form a new organisation for their purpose if they wish, but the national executive will only recognise those standing by the constitution." 82 This was followed by a national intervention to reconstitute the Christchurch branch, with the national executive electing new officers among whom, as the New Zealand Herald put it, "extremists are missing." 83

The league then recommitted itself to renewed lobbying on established concerns. On 25 May the leadership made another attempt to petition the government for an increase in separation allowances on the nest egg principle, calling for sensitivity regarding the welfare needs and business concerns that the removal of married breadwinners would create. ${ }^{84}$ They also raised new proposals to stretch the First Division. Examples included calls for reassessments of exempted men under stricter criteria, the removal of exemptions for essential work and the reorganisation of agriculture to "comb out" more First Division farm workers. ${ }^{85}$ In some districts, branches formed committees with the intent to "assist the military representative on the Military Service Board" and "review the bona-fides of every exempted reservist." 86

However, attitudes to the Second Division question now encountered a mood of official firmness and hardened public reception. Allen proved unyielding on ambitions to renegotiate allowances. On 14 May, in a letter to Massey, he outlined his disposition:

I propose to tell the League if they come to me that the Government have carefully considered the question of allowances and believe that they have acted liberally. My opinion is that it is best to make a straight out statement to them that we have done all we deem it desirable to do, except that we will make an honest attempt to provide 
for the soldier on return who has no billet to go into during the time between his discharge and securing employment. ${ }^{87}$

This became the basis of the Cabinet position announced at the end of May. ${ }^{88}$ Likewise, the league's demand for ever tougher exemption standards for First Division men was unsympathetically received. Potentially influencing this position was the fact that the review of First Division exemption cases had concluded with the specification that "no further appreciable combing out is possible if production and essential trades and industries ... are to be maintained at the present standard." This effort had reassessed 5,771 cases and directed 900 formerly exempted men into training camps. ${ }^{89}$

Some league commentary reacted to this hardened official position with calls for the league to campaign to the public: "It was plain from the attitude of the [Defence] Minister that he had no desire to meet the position as it should be met, and the league had no alternative but to organise right through the dominion and bring the pressure of public opinion to bear on the Minister." 90 However, the league's store of public goodwill, and standing in the politics of sacrifice, had declined from that of a year ago. Second Division declarations of being willing to serve when the time came were now mocked as cases of protesting too much (figure 3). Comments like "we object to going while there are so many exempted First Division men" drew hostile ripostes, especially from returned soldiers and relatives of soldiers. ${ }^{91}$ Thus "another returned soldier" protested that "the married men are willing to make great sacrifices — of other men's blood. Their wives and children are so dear to them ... But they won't go and fight for them. They talk, they wrangle, they clamour while real men do and die." 92 "Returned Soldier" similarly noted:

These are the men who made an unfit single man's life scarcely worth living with jeers of "Shirker!" and questions such as "What did you do in the great war, daddy?" And now that the ranks of the single men are so depleted, what do we find when the time comes for the married men to help the boys in the trenches to fight their own battles? ... It is a pity that more of the babies whom these shirkers are hiding behind are not old enough to shame their fathers by asking, "What are you doing in the great war, daddy?"93

"Mother of a married returned man" concurred:

I asked nothing from the Government towards my support. I was, and am, glad to know I had a son able and, more than that, willing, to fight for the freedom of the civilised world. He, my son, returned "a down and outer." I would gladly, although an old woman, take his place, if I could ... Why will the Second Division men haggle over a few shillings when, if they don't help crush Germany, Germany will have no hesitation in crushing them. ${ }^{94}$ 


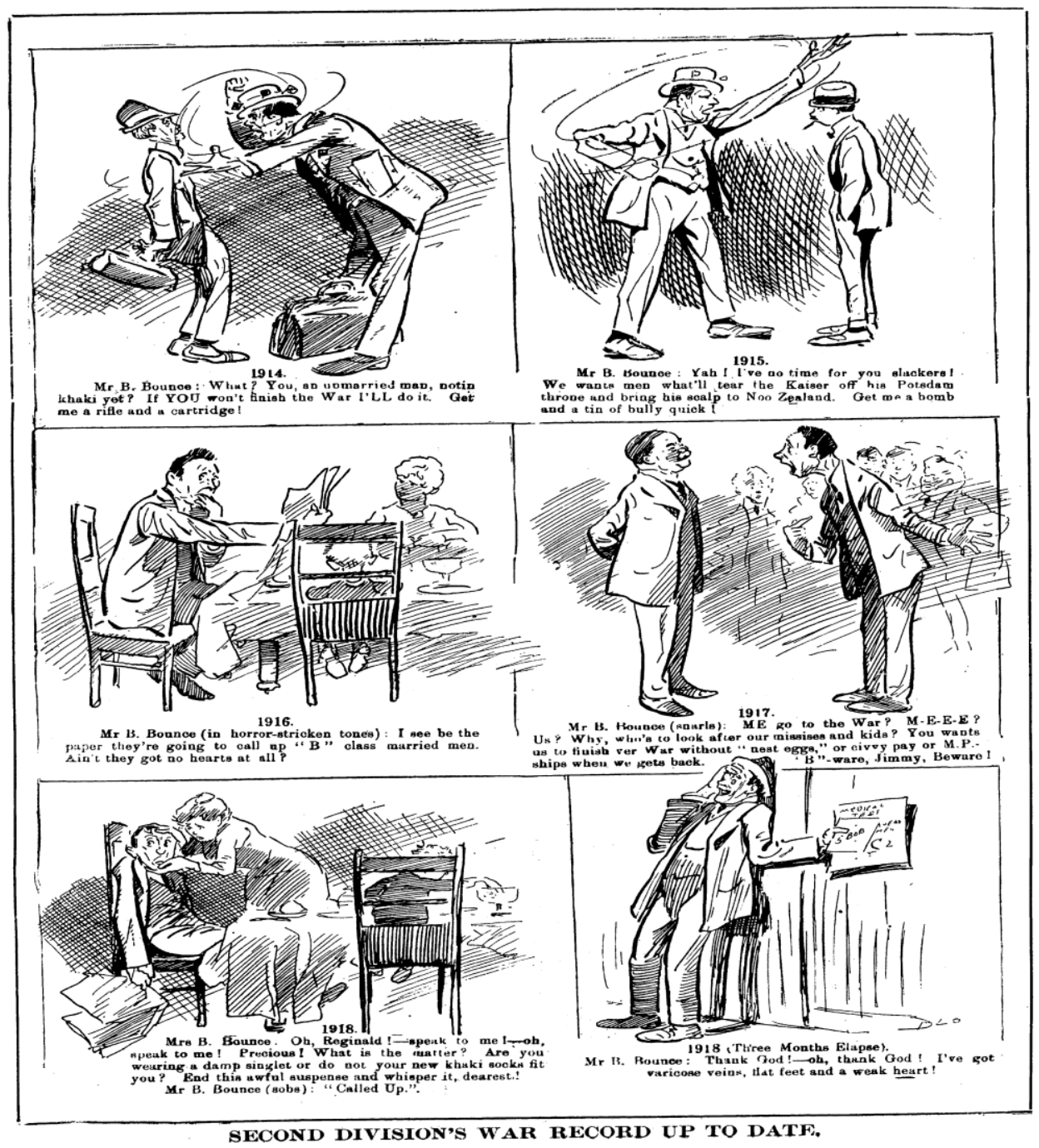

Figure 3: New Zealand Observer, 6 July 1918, 12.

The absence of state and/or social backing and an unwillingness to take direct action saw the league's momentum for winning further concessions wane. This internal resignation seems evident in the league's minutes past mid-1918, with past accomplishments, complaints of declining attendance and an increasing refocus on repatriation policies forming prominent subjects. ${ }^{95}$ Some acceptance of the status quo also potentially derived from the high exemption rates of balloted Second Division men (a point also evident in the final panel of figure 3 ). Indeed, while 54,549 Second Division men (13,466 Class A; 17,507 Class B; 23,576 Class C) were balloted between October 1917 and November 1918, exemptions meant that 68 percent of these ballots did not translate into military service. ${ }^{96}$ By the end of the war, only 832 Second Division conscripts (796 Class A; 32 Class B; 4 Class C) had embarked, and these men appear to have all been in England at the time of the Armistice. ${ }^{97}$ In Baker's words: "by luck and judgement the Government and the Second Division League had actually managed to keep all married conscripts out of the firing line. Potentially the greatest financial and social traumas of the war had been avoided." 98 By contrast, the consequences of sending masses of conscripted family men to war were not hypothetical for many European belligerents. ${ }^{99}$

Journal of New Zealand Studies NS27 (2018), 16-34

https://doi.org/10.26686/jnzs.v0iNS27.5174 


\section{Conclusion}

The events and dynamics that emerged from efforts to answer the Second Division question serve to illustrate the conditional aspects operating within New Zealand's commitment to the war. This conditional commitment indicates how the boundaries of consent for or dissent from the war could shift, and were contingent on various circumstances. Such behaviour represents a significant dynamic within the wartime social mobilisation and contrasts with cases of rigid commitment and unconditional dissent.

Throughout the episode, multiple factors can be identified as acting to shape the conditions of service. The first of these is the demand sustained mobilisation placed on the social body, which saw the proclivity to exempt family men eroded by the need for sustained reinforcements. Consequently the extension of conscription to these men loomed as a possibility, then as a reality, in the final period of the war. A further indication of the role war-related circumstances played is the way that tensions were only dispelled when the Armistice radically transformed the situation.

The efforts of various negotiating parties forms a second major factor. The government's efforts to delay, and perhaps avoid, a mobilisation of family men constitutes an early example of efforts to mediate how the demands of the war impacted society. The structuring of conscription institutionalised this ambition and continued the tactic of delaying Second Division mobilisation. The use of negotiation continued once circumstances augured the coming reality of Second Division conscripts. The Second Division League's lobbying revolved around conditional commitment, proclaiming that its members would trade consent for concessions. In its early period, the league proved capable of successfully levering this dynamic and its results can be measured in the various allowances conceded by the government.

However, if the posture of conditional commitment proved an apt negotiating position, its limits were also apparent. Indeed, the Second Division question constitutes a case where tensions escalated despite the existence of channels for mediation, stores of goodwill between negotiators and shared recognition of legitimate goals. The league's success in leveraging conditional commitment began to shift as public and official affirmation of the league's legitimacy waned. That legitimacy was built on a broad acceptance that the league's mission to protect Second Division dependants was honourable and that consent to the war would follow the awarding of what were seen as reasonable concessions. Thus, the dissent accompanying the commencement of Second Division conscription could be taken as marking the limits of efforts to mutually satisfy all parties. Subsequent remobilisation reflects efforts to assert the established conditions of commitment. The degrees of coercion and compromise employed included state efforts to isolate radicals as well as the manner in which public opinion acted to threaten, or deny, the league's legitimacy and call for compliance. This pressure proved successful in containing the radical aspects of the league and the degree of dissent that had built around the Second Division question.

Journal of New Zealand Studies NS27 (2018), 16-34

https://doi.org/10.26686/jnzs.v0iNS27.5174 
${ }^{1}$ For literature touching on New Zealand families during the Great War, see Kathryn M. Hunter, Australian and New Zealand Fathers and Sons During the Great War: Expanding the Histories of Families at War," First World War Studies 4, no. 2 (2013): 185-200; Rachel Patrick, "An Unbroken Connection? New Zealand Families, Duty, and the First World War" (PhD thesis: Victoria University of Wellington, 2014).

${ }^{2}$ Archives New Zealand, R22436341-AAYS-8638-AD1-1046-66/23, "Conscription-Medical examination of members of 2nd Division," correspondence from A. L. Herdman to Messrs. Joseph and Nathan, 2 February 1917.

${ }^{3}$ For an overview of New Zealand society's commitment to the war, see Steven Loveridge, Calls to Arms: New Zealand Society and Commitment to the Great War (Wellington: Victoria University Press, 2014).

${ }^{4}$ For examples, see H. E. Holland, Armageddon or Calvary: The Conscientious Objectors of New Zealand and "the Process of their Conversion" (Wellington: Maoriland Worker Printing, 1919); P.S. O'Connor, "The Awkward Ones-Dealing with Conscience, 1916-1918," New Zealand Journal of History 8, no. 2 (October 1974): 118-36; Paul Baker, King and Country Call: New Zealanders, Conscription and the Great War (Auckland: Auckland University Press, 1988), 73-78; Megan Hutching, "Mothers of the World': Women, Peace and Arbitration in Early Twentieth-Century New Zealand," New Zealand Journal of History 27, no. 2 (October 1993): 173-85; J. E. Cookson, "Pacifism and Conscientious Objection in New Zealand," in Challenge to Mars: Essays on Pacifism from 1918 to 1945, ed. Peter Brock and Thomas P. Socknat (Toronto: University of Toronto Press, 1999), 292-311; David Grant, Field Punishment No. 1: Archibald Baxter, Mark Briggs and New Zealand's Anti-Militarist Tradition (Wellington: Steele Roberts, 2008); various examples within Geoffrey Troughton, ed., Saints and Stirrers: Christianity, Conflict and Peacemaking in New Zealand, 1814-1945 (Wellington: Victoria University Press, 2017).

${ }^{5}$ David Stevenson, 1914-1918: The History of the First World War (London: Penguin, 2012), 104. For a dedicated study of the dynamic across the British Empire, see Douglas E. Delaney and Nikolas Gardner, ed., Turning Point 1917: The British Empire at War, (Vancouver; University of British Columbia Press, 2017).

${ }^{6}$ Baker, King and Country Call, 152.

${ }^{7}$ Steven Loveridge, "Introduction: A Small Land in a World War," in New Zealand Society at War, 1914-1918, ed. Steven Loveridge (Wellington: Victoria University Press, 2016), 31.

${ }^{8}$ Judith Bassett, "Colonial Justice the Treatment of Dalmatians in New Zealand during the First World War," New Zealand Journal of History 33, no. 2 (October 1999): 155-79; Steven Loveridge and James Watson, "Economic Mobilisation: New Zealand Businesses and the Great War," in New Zealand Society at War, ed. Loveridge, 159-74; Brad Patterson, " "We Stand for the Protestant Religion, the (Protestant) King and the Empire': The Rise of the Protestant Political Association in World War One," New Zealand Society at War, ed. Loveridge, 235-51; Loveridge and Basil Keane, "Turangawaewae: Maori Relationships with the Great War," in New Zealand Society at War, ed. Loveridge, 281-96.

${ }^{9}$ John Horne, "Remobilizing for 'Total War': France and Britain, 1917-1918," in State, Society and Mobilization in Europe during the First World War, ed. John Horne (Cambridge: Cambridge University Press, 1997), 195-211.

${ }^{10}$ Some nascent thoughts are evident within Loveridge, "Introduction," in New Zealand Society at War, ed. Loveridge, 15-33 and Margaret Levi, "The Institution of Conscription," Social Science History 20, no. 1 (1996): 133-67.

${ }^{11}$ For details on the structure of war widows' pensions and separation allowances, see Melanie Nolan, Breadwinning: New Zealand Women and the State (Christchurch: Canterbury University Press, 2000), $87-102$.

${ }^{12}$ Star, 26 May 1915, 4.

${ }^{13}$ New Zealand Herald, 25 May 1915, 8. 
${ }^{14}$ Baker, King and Country Call, 57.

${ }^{15}$ The Bill recognised four categories: "unmarried men," "men whose marriage took place subsequently to the first day of May, nineteen hundred and fifteen, except such that have a child under sixteen years of age by a previous marriage," "widowers with no children under sixteen years of age," and "men whose marriage has been dissolved or who are judicially separated from their wives by decree of judicial separation, separation order, or otherwise, and who have no children under sixteen years of age." New Zealand Statutes, 1916, No. 8, "Military Service Act," section 4.

${ }^{16}$ For the workings of New Zealand's Military Service Boards which assessed nonmedical appeals for exemption, see David Littlewood, "Striking a Balance: The Military Service Boards," New Zealand Society at War, ed. Loveridge, 112-26.

${ }^{17}$ R. A. Armstrong, Handbook for Reservists: A Summary of The Benefits Provided for Soldiers and Their Dependants by Legislation and Regulation with Instructions as to Best Methods of Obtaining Same, and General Hints to Reservists (Auckland: Auckland Second Division League, 1918), 5. These regulations were publicly announced in the Evening Post, 4 July 1917, 7.

${ }^{18}$ New Zealand Herald, 10 January 1917, 6. For a broader context on the strains of New Zealand manpower over 1917, see John Crawford, “The Willing Horse is Being Worked to Death': New Zealand's Manpower Problems and Policies during 1917," in Turning Point 1917, ed. Delaney and Gardner, 114-38.

${ }^{19}$ Truth, 31 March 1917, 5.

${ }^{20}$ New Zealand Herald, 4 May 1918, 6. For other examples of commercial responses, see New Zealand Herald, 11 May 1918, 6 and Handbook for Reservists.

${ }^{21}$ Baker notes that James Allen was "probably grateful for such an apparently moderate group with which to negotiate the tricky issues arising from the conscription of married men." Baker, King and Country Call, 143.

${ }^{22}$ Graham Hucker, "When the Empire Calls: Patriotic Organisations in New Zealand during the Great War" (MA Thesis, Massey University, 1979), 47.

${ }^{23}$ New Zealand Herald, 11 July 1917, 8; Otago Daily Times, 20 April 1917, 7.

${ }^{24}$ Proceedings of the Second Division League Conference Wellington, July 18-20, 1917 (New Plymouth: Taranaki Daily News Print, 1917), 1-2.

${ }^{25}$ Proceedings of the Second Division League Conference, 5. Emphasis added.

${ }^{26}$ Proceedings of the Second Division League Conference, 28.

${ }^{27}$ Jay Winter and Antoine Prost, The Great War in History: Debates and Controversies, 1914 to the Present (New York: Cambridge University Press, 2005), 97.

${ }^{28}$ Maoriland Worker, 27 June 1917, 3.

${ }^{29}$ New Zealand Herald, 28 February 1917, 8.

${ }^{30}$ Evening Star, 28 February 1917, 4.

${ }^{31}$ For further details, see Gwen Parsons, "The Christchurch Community at War, 1914-1918: Society, Discourse and Power" (MA thesis, University of Canterbury, 2003). This research is adapted in Parsons, "Debating the War: The Discourses of War in the Christchurch Community," in New Zealand's Great War: New Zealand, the Allies and the First World War, ed. John Crawford and Ian McGibbon (Auckland: Exisle Publishing, 2007), 550-68. For a wider context on Christchurch radicalism, see Jim McAloon, "Radical Christchurch," in Southern Capital: Christchurch Towards a City Biography, 1850-2000, ed. John Cookson and Graeme Dunstall (Christchurch: Canterbury University Press, 2000), 162-92.

${ }^{32}$ New Zealand Free Lance, 18 May 1917, 3.

${ }^{33}$ Evening Star, 28 February 1917, 4.

${ }^{34}$ New Zealand Parliamentary Debates, Vol. 178, 20 July 1917, 635.

${ }^{35}$ Proceedings of the Second Division League Conference.

${ }^{36}$ Archives New Zealand, R22436341-AAYS-8638-AD1-1046-66/23, "Conscription-Medical Examination of Members of 2nd Division," correspondence from A. L. Herdman to Messrs. Joseph and Nathan, 2 February 1917.

Journal of New Zealand Studies NS27 (2018), 16-34

https://doi.org/10.26686/jnzs.v0iNS27.5174 
${ }^{37}$ Archives New Zealand, R22319675-ADBQ-16145-ALLEN1-9, "Miscellanous [sic] Files and Papers-Correspondence Between J. Allen and W. F. Massey, 1st September 1916-1st August 1919 [loose papers]," correspondence from Allen to Massey, 7 May 1917.

${ }^{38}$ Proceedings of the Second Division League Conference, 2.

${ }^{39}$ Baker, King and Country Call, 57.

${ }^{40}$ New Zealand Herald, 20 March 1917, 4.

${ }^{41}$ Archives New Zealand, R22436353-AAYS-8638-AD1-1046-66/46, "Conscription-BallotSecond Division-Arrangements," memorandum for the Minister of Defence, 21 December 1917. ${ }^{42}$ Archives New Zealand, R22436341-AAYS-8638-AD1-1046-66/23, "Conscription-Medical Examination of Members of 2nd Division," correspondence from A. L. Herdman to Messrs. Joseph and Nathan, 2 February 1917; Archives New Zealand, R10075043-AAYS-8698-AD82-8-60, "2nd Division-General, February-September 1917."

${ }^{43}$ Evening Post, 27 September 1917, 6.

${ }^{44}$ A selection of protest letters is collected with the defence file Archives New Zealand, R22433708AAYS-8638-AD1-831-29/267, "Establishments and Recruitment-Ages-Recruits for Expeditionary Force."

${ }^{45}$ Evening Post, 10 August 1917, 7.

${ }^{46}$ Maoriland Worker, 18 July 1917, 1.

${ }^{47}$ Archives New Zealand, R22433708-AAYS-8638-AD1-831-29/267, "Establishments and Recruitment-Ages-Recruits for Expeditionary Force," memorandum, 12 September 1917.

${ }^{48}$ Dominion, 28 September 1917, 7.

${ }^{49}$ Evening Post, 27 September 1917, 6.

${ }^{50}$ New Zealand Observer, 6 October 1917, 1.

${ }^{51}$ Ashburton Guardian, 17 October 1917, 5.

${ }^{52}$ Details available at "Recruiting and Conscription," https://nzhistory.govt.nz/war/recruiting-andconscription (Ministry for Culture and Heritage).

${ }^{53}$ New Zealand Herald, 1 October 1917, 4.

${ }^{54}$ Truth, 13 October 1917, 5. Truth's editorial line broadly accepted the cause of the war but proved a steady critic of how authorities managed the war effort. For further analysis, see Redmer Yska, "The First World War and Truth," in How We Remember: New Zealanders and the First World War, ed. Charles Ferrall and Harry Ricketts (Wellington: Victoria University Press, 2014), 147-59.

${ }^{55}$ New Zealand Herald, 21 February 1918, 4. Despite the league abstaining from direct involvement in politics, conscription and equality of sacrifice were major issues within the by-election as Labour MP Henry Holland made them, as well as profiteering, part of his campaign platform. While Reform retained the, safely conservative, electorate, the result shocked the government, as Labour's share of the vote increased from near 15 percent to near 36 percent. See Barry Gustafson, Labour's Path to Political Independence: The Origins and Establishment of the New Zealand Labour Party 1900-19 (Auckland: Auckland University Press, 1980), 132.

${ }^{56}$ Truth, 16 February 1918, 6.

${ }^{57}$ Press, 5 February 1918, 7.

${ }^{58}$ Press, 3 May 1918, 6.

${ }^{59}$ Truth, 4 May 1918, 5.

${ }^{60}$ Truth, 4 May 1918, 5.

${ }^{61}$ Truth, 4 May 1918, 5; Press, 29 April 1918, 7.

${ }^{62}$ New Zealand Herald, 30 April 1918, 6.

${ }^{63}$ New Zealand Herald, 30 April 1918, 6.

${ }^{64}$ New Zealand Herald, 30 April 1918, 6.

${ }^{65}$ New Zealand Herald, 30 April 1918, 6.

${ }^{66}$ Press, 30 April 1918, 7.

${ }^{67}$ The full details are available in Evening Post, 30 April 1918, 6.

${ }^{68}$ Evening Post, 30 April 1918, 6.

Journal of New Zealand Studies NS27 (2018), 16-34

https://doi.org/10.26686/jnzs.v0iNS27.5174 
${ }^{69}$ Evening Post, 30 April 1918, 6.

${ }^{70}$ For details on the anti-German riots see Andrew Francis, "To Be Truly British We Must Be AntiGerman": New Zealand, Enemy Aliens and the Great War Experience, 1914-1919 (New York: Peter Lang, 2012), 93-95. For details on the police raid on Maungapohatu, see Judith Binney, Gillian Chaplin, and Craig Wallace, Mihaia: The Prophet Rua Kenana and His Community at Maungapohatu (Wellington: Oxford University Press, 1979), 261. For more on the situation in Christchurch, see P. S. O'Connor, "Balmy Christchurch: A Melodrama in Three Parts," Comment: New Zealand Quarterly Review, 35 (June 1968), 21-28.

${ }^{71}$ The following accounts are taken from Press, 30 April 1918, 3 and Truth, 4 May 1918, 5.

${ }^{72}$ New Zealand Herald, 1 May 1918, 6.

${ }^{73}$ Baker, King and Country Call, 149.

${ }^{74}$ Evening Star, 1 May 1918, 4.

${ }^{75}$ Archives New Zealand, R22319706-ADBQ-16145-ALLEN1-12, "Miscellanous [sic] Files and Papers-Miscellaneous Correspondence and Papers [loose papers]," correspondence from Isitt to Allen, 30 April 1918.

${ }^{76}$ Press, 3 May 1918, 6.

${ }^{77}$ New Zealand Herald, 9 May 1918, 4. Hiram Hunter was a former National Secretary of the Social Democratic Party and, at the time of the protest, was National Secretary and Treasurer of the United Federation of Labour and a Christchurch City Councillor. Though strongly supportive of the British Empire and the war, he was strongly opposed to conscription. See Gustafson, Labour's Path to Political Independence, 159.

${ }^{78}$ Press, 20 May 1918, 6; North Otago Times, 22 May 1918, 2.

${ }^{79}$ New Zealand Free Lance, 9 May 1918, 8.

${ }^{80}$ Press, 3 May 1918, 6.

${ }^{81}$ Press, 3 May 1918, 6.

${ }^{82}$ New Zealand Herald, 4 May 1918, 6.

${ }^{83}$ New Zealand Herald, 17 May 1918, 6.

${ }^{84}$ New Zealand Herald, 25 May 1918, 6.

${ }^{85}$ New Zealand Herald, 11 May 1918, 8; New Zealand Herald, 4 May 1918, 7.

${ }^{86}$ New Zealand Herald, 4 May 1918, 7.

${ }^{87}$ Archives New Zealand, R22319675-ADBQ-16145-ALLEN1-9, "Miscellanous [sic] Files and Papers-Correspondence Between J. Allen and W. F. Massey, 1st September 1916-1st August 1919 [loose papers]," correspondence from Allen to Massey, 14 May 1918.

${ }^{88}$ Waikato Times, 30 May 1918, 5.

${ }^{89}$ Archives New Zealand, R22429828-AAYS-8638-AD1-736-10/512, “Territorial Force-

Exemption-Reservists under Military Service Act,” Memorandum for James Allen, 20 May 1918.

${ }^{90}$ Otago Daily Times, 26 June 1918, 2.

${ }^{91}$ New Zealand Herald, 13 May 1918, 7. The RSA constituted an organised detractor and, noting that it was "disgusted with [Second Division League] demands," urged the government to stand firm. New Zealand Herald, 23 May 1918, 4.

${ }^{92}$ New Zealand Herald, 17 May 1918, 8.

${ }^{93}$ Press, 3 May 1918, 6.

${ }^{94}$ New Zealand Herald, 10 June 1918, 6.

${ }^{95}$ For example, Press, 17 July 1918, 7; Ashburton Guardian, 8 June 1918, 2; Marlborough Express, 8 November 1918, 2.

${ }^{96}$ Appendix to the Journals of the House of Representatives, 1919, H-19, 14.

${ }^{97}$ Appendix to the Journals of the House of Representatives, 1919, H-19, 15; Baker, King and Country Call, 151.

${ }^{98}$ Baker, King and Country Call, 151.

${ }^{99}$ For example, estimates for French war widows stand at 600,000, and estimates for French war orphans range between 760,000 and 1.2 million. Leonard V. Smith, Stéphane Audoin-Rouzeau, and

Journal of New Zealand Studies NS27 (2018), 16-34

https://doi.org/10.26686/jnzs.v0iNS27.5174 
Annette Becker, France and the Great War 1914-1918 (New York: Cambridge University Press, 2003), 70. Another study cites an estimated a total of 6 million war orphans resulting from the conflict: see Andrew Donson, "Children and Youth," in 1914-1918 Online: International Encyclopedia of the First World War, ed. Ute Daniel, Peter Gatrell, Oliver Janz, Heather Jones, Jennifer Keene, Alan Kramer, and Bill Nasson (Berlin, Freie Universität Berlin, 2014), DOI: $\underline{10.15463 / \mathrm{ie} 1418.10265}$, note 44 . 